\title{
In Vivo Electroporation Induces Cell Cycle Reentry of Myonuclei in Rat Skeletal Muscle
}

\author{
Takahiro MIYOSHI ${ }^{1)}$, Shin-ichi NAKANO ${ }^{1)}$, Katsuyuki NAKAMURA ${ }^{1)}$, Keitaro YAMANOUCHI ${ }^{1) *}$ and \\ Masugi NISHIHARA ${ }^{1)}$ \\ 1) Department of Veterinary Physiology, Graduate School of Agricultural and Life Sciences, The University of Tokyo, 1-1-1 Yayoi, \\ Bunkyo-ku, Tokyo 113-8657, Japan
}

(Received 30 April 2012/Accepted 17 May 2012/Published online in J-STAGE 31 May 2012)

ABSTRACT. Adult urodele amphibians such as newts are capable of regenerating lost structures including their limbs. In these species, dedifferentiation of myofiber is essential for the regenerative process. Upon terminal differentiation, nuclei of myofiber (myonuclei) are withdrawn from cell cycle, but prior to dedifferentiation, myonuclei reenter the cell cycle. In contrast with urodele amphibians, it is generally accepted that mammalian myofibers are not able to dedifferentiate in response to muscle injury. A recent study has suggested that electroporation can induce dedifferentiation response of skeletal muscle in newt limbs. In the present study, we examined whether myonuclei of skeletal muscle of mammals are capable of reentering the cell cycle by means of electroporation. Electroporation was applied to tibialis anterior muscle of the rat with or without plasmid DNA. Histological analyses revealed that, while electroporation induces degenerative/regenerative responses in skeletal muscle irrespective of the presence of plasmid DNA, the expression of proliferating cell nuclear antigen (PCNA) in myonuclei was observed only in the presence of plasmid DNA. The present results indicate that myonuclei of skeletal muscle are capable of reentering the cell cycle and suggest that in vivo electroporation can induce dedifferentiation of mammalian skeletal muscle.

KEY WORDS: cell cycle reentry, dedifferentiation, electroporation, rat, skeletal muscle.

doi: 10.1292/jvms.12-0195; J. Vet. Med. Sci. 74(10): 1291-1297, 2012

Urodele amphibians, such as newts and axolotls, can regenerate lost structures and organs, including their limbs, tail, jaws, spinal cord, retinas, lenses, optic nerves, intestine, and a part of heart ventricle through dedifferentiation [34]. In amphibian limb amputation, epithelial cells begin to migrate and cover the amputation site, forming a wound epithelium. The wound epithelium thickens and forms a mature apical epithelial cap (AEC). Under the AEC, tissues including epidermis, dermis, cartilage, bones, skeletal muscle and Schwann cells dedifferentiate and form a pool of progenitor cells known as the regeneration blastema, in which cells re-differentiate to form lost structures [21]. Besides these dedifferentiated cells, stem cells residing within tissues are also thought to constitute the regeneration blastema $[10,30]$. However, neither such remarkable regenerative capabilities nor the blastema formation is observed in mammals.

In mammals, skeletal muscle is composed of multinucleated myofibers that are separated from each other by a basement membrane and a sarcolemma [9]. Between the basement membrane and the sarcolemma, there are satellite cells, which are activated in response to muscle damage and differentiate to form new myofibers. This differentia-

\footnotetext{
*Correspondence to: Yamanouchi, K., Department of Veterinary Physiology, Graduate School of Agricultural and Life Sciences, The University of Tokyo, 1-1-1 Yayoi, Bunkyo-ku, Tokyo 1138657, Japan.

e-mail: akeita@mail.ecc.u-tokyo.ac.jp

(C)2012 The Japanese Society of Veterinary Science
}

tion process is characterized by the irreversible withdrawal of satellite cells from the cell cycle. In the regeneration process of amphibians, the dedifferentiation of myofibers is the major cell source for blastema formation [13]. Cell cycle reentry of myonuclei and fragmentation of myofiber are considered to be specific indicators of dedifferentiation $[6,7,33]$. In mammalian systems, there are several studies to induce dedifferentiation of $\mathrm{C} 2 \mathrm{C} 12$ myotubes in vitro, including the ectopic expression of homeobox-containing transcriptional repressor msxl [35], the treatment by myoseverin, a microtubule-binding molecule [38], and the overexpression of Twist, a nuclear basic helix-loop-helix transcription factor [19]. In these studies, nuclei of C2C12 myotubes reenter the cell cycle, and these myotubes are cleaved into proliferative mononucleated cells. Moreover, a recent study showed that murine myofibers may be able to dedifferentiate by skeletal muscle injury in vivo [31]. These results indicate that mammalian skeletal muscle has a potential to dedifferentiate.

Electroporation is known as an efficient technique for gene transfer [2], and its uses for gene therapy have been extensively studied $[11,26]$. Besides these uses for gene transfer, a recent study showed that electroporation to newt appendages can induce the dedifferentiation response that is indistinguishable from the response after amputation [3]. In the present study, we examined whether mammalian myofibers can reenter the cell cycle after electroporation. The results suggested that mammalian myofibers may have a potential to dedifferentiate when exposed to the appropriate stimulation of electric pulses. 


\section{MATERIALS AND METHODS}

Animals: Adult (9 to 14 weeks old) male Wistar Imamichi rats purchased from Institute for Animal Reproduction (Ibaraki, Japan) were used throughout this study. They were housed in a room at $23^{\circ} \mathrm{C}$ with a lighting condition of 12 hr-light and $12 \mathrm{hr}$-darkness (lights on at $0800 \mathrm{hr}$ ). Food and water were provided ad libitum. All animal experiments performed in this study were according to the Guideline for the Care and Use of Laboratory Animals, The University of Tokyo.

Plasmid DNA: Plasmid pCAGGS-lacZ, which drives lacZ cDNA expression under the CAG (cytomegalovirus immediate-early enhancer-chicken $\beta$-actin hybrid) promoter [32], was kindly gifted from Dr. Masahiro Sato, Kagoshima University. Plasmid was purified by ethidium bromide- $\mathrm{CsCl}$ equilibrium density gradient ultracentrifugation.

Electroporation: Rats were anesthetized by ethyl ether, and their skin over tibialis anterior muscle (TA, also termed cranial tibial muscle) was incised. A pair of stainless electrode needle was stuck into TA muscle, and $100 \mu l$ of plasmid solution ( $1 \mathrm{mg} / \mathrm{ml}$ pCAGGS-lacZ) was injected between needles. Immediately after the injection, three square pulses of $50 \mathrm{~V}$ for $50 \mathrm{msec}$ were applied at $100 \mathrm{msec}$ intervals, followed by three more pulses of the opposite polarity using an electroporator (CUY21, NEPA GENE CO., Ltd., Chiba, Japan). On the indicated days after electroporation, the rats were sacrificed by inhalation of carbon dioxide gas, and their TA muscles were obtained. The tissue samples were snapfrozen in isopentane cooled with liquid nitrogen, and stored at $-85^{\circ} \mathrm{C}$ until use.

Bupivacaine hydrochloride (BPVC) injection: Rats were anesthetized by ethyl ether, and $200 \mu l$ of BPVC (Sigma, St. Louis, MO, U.S.A.; $0.75 \%$ in saline) was injected into TA muscles. On the indicated days after the injection, TA muscles were isolated and frozen as described above.

Histological analyses: Frozen sections (7-8 $\mu \mathrm{m}$ thickness) of the rat TA muscles were prepared transversely, and nearly the broadest sections were subjected to histological analyses. For hematoxylin-eosin (HE) staining, sections were fixed with $4 \%$ paraformaldehyde in phosphate buffered saline (4\% PFA/PBS). After washing with running tap water for $5 \mathrm{~min}$, sections were stained with hematoxylin. After washing with running tap water for $10 \mathrm{~min}$, the sections were immersed in eosin solution for $3 \mathrm{~min}$, then dehydrated and mounted with Multi Mount 220 (Matsunami Glass Ind., Ltd., Osaka, Japan).

For immunohistochemistry, the sections were fixed with $4 \%$ PFA/PBS for $15 \mathrm{~min}$ at room temperature (RT) and washed with PBS. Then, the sections were incubated in methanol for $20 \mathrm{~min}$ at RT. After washing with PBS, the sections were blocked with 5\% normal goat serum (NGS) in PBS for $30 \mathrm{~min}$. After blocking, the sections were incubated with primary antibody for $2 \mathrm{hr}$ at RT. The following primary antibodies were used: anti-PCNA (clone PC10 from Santa Cruz Biotechnology, Santa Cruz, CA, U.S.A., 1:100 dilution), and anti-dystrophin (clone H-300 from Santa Cruz Biotechnology, 1:100 dilution). The sections were washed with PBS and incubated with secondary antibody for $1 \mathrm{hr}$ at RT. The following secondary antibodies were used: Alexa Fluor 488-labeled anti mouse IgG (Invitrogen, Carlsbad, CA, U.S.A., 1:400 dilution) and Alexa Fluor 594-labeled anti rabbit IgG (Invitrogen, 1:400 dilution). All the antibodies were diluted with 5\% NGS/PBS. Cell nuclei were counterstained with Hoechst 33258. Fluorescent signals were observed with a fluorescent microscope. When quantitative analyses on immunopositive nuclei were performed, the number of positive nuclei within sarcolemma on entire section was counted.

$\beta$-galactosidase staining: Sections were fixed with $2 \%$ PFA, $0.2 \%$ glutaraldehyde in PBS for $5 \mathrm{~min}$ at RT and washed with PBS. Then, the sections were incubated with $\mathrm{X}$-gal solution $[1 \mathrm{mg} / \mathrm{m} /$ 5-bromo-4-chloro-3-indolyl- $\beta$-Dgalactoside (X-gal)], $5 \mathrm{mM}$ potassium ferricyanide, $5 \mathrm{mM}$ potassium ferrocyanide and $2 \mathrm{mM}$ magnesium chloride in PBS for $6 \mathrm{hr}$ at $37^{\circ} \mathrm{C}$ and washed with PBS. Cell nuclei were counterstained with hematoxylin, and the sections were washed with running tap water for $10 \mathrm{~min}$, dehydrated and mounted.

Statistical analyses: ANOVA followed by Tukey-Kramer post-hoc comparisons were used to evaluate statistical differences among the groups. $P$ values less than 0.05 were considered statistically significant.

\section{RESULTS}

Electroporation induces degenerative/regenerative response in skeletal muscle: Electroporation is known to induce degenerative/regenerative response of skeletal muscle [5, 37]. To examine the electroporation-induced degenerative/regenerative response in skeletal muscle, histological analyses were performed on rat TA muscles after electroporation with plasmid DNA (pCAGGS-lacZ). On day 1 after electroporation, HE staining revealed the degenerative changes of myofibers and the infiltration of mononucleated cells, presumably inflammatory cells (Fig. 1A, Day 1). On day 3, much more mononucleated cells were present in the degenerated area (Fig. 1A, Day 3). On days 5 and 7, the number of mononucleated cells was decreased, and newly formed multinucleated myotubes appeared, indicating the ongoing regenerative process (Fig. 1A, Days 5 and 7). On day 10, immature myofibers with central nuclei were observed mainly, but the regeneration was yet to be completed. (Fig. 1A, Day 10).

We next investigated the lacZ expression during regenerative process of skeletal muscle. The lacZ expression was observed from day 1 to day 7 after electroporation, but disappeared on day 10 (Fig. 1B). In the period when the lacZ expression was observed, almost all of the lacZpositive cells were mature myofibers, and lacZ-positive mononucleated cells were rarely observed (Fig. 1B, Day 1). On days 5 and 7, lacZ expression was detected in the newly formed multinucleated myotubes (Fig. 1B, Day 5). The results confirmed that electroporation induces degenerative/ regenerative response in skeletal muscle, and indicated that the plasmid DNA was introduced into the cells that would participate in the formation of new myofibers, as well as into mature myofibers. 
A)



B)

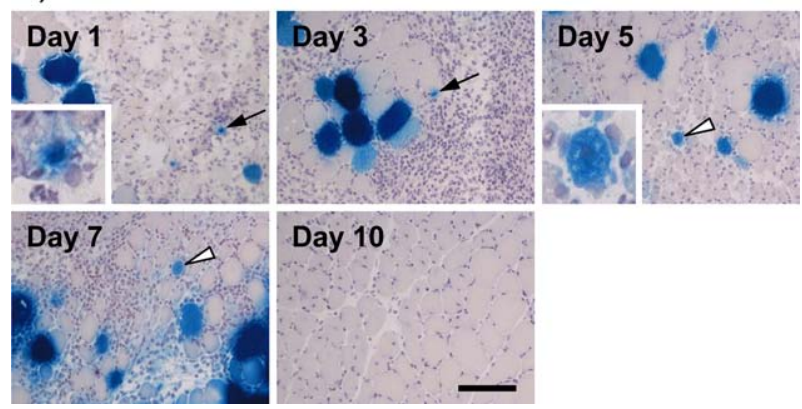

Fig. 1. Histological analyses of rat TA muscles after electroporation. Frozen sections of rat TA muscles obtained on days 1, 3, 5, 7, and 10 after electroporation with plasmid DNA (pCAGGS-lacZ) were stained with $\mathrm{HE}(\mathrm{A})$, and for $\beta$-galactosidase activity (B). In A, black arrowheads indicate newly formed myotubes with central nuclei. In B, black arrows indicate lacZ-positive mononucleated cells, whereas white arrowheads indicate lacZ-positive myotubes with central nuclei. Insets are magnified images of indicated cells in corresponding panels. Scale bar $=100 \mu \mathrm{m}$.

Electroporation induces cell cycle reentry of myonuclei: Cell cycle reentry of nuclei of mature myofibers is a potential indicator of cellular plasticity and considered to be a specific feature observed in the dedifferentiation process of skeletal muscle $[6,33]$. The above results that lacZ expression was mainly observed in newly formed myotubes, but not in mononucleated cells, raised the possibility that dedifferentiation of myofibers could take place after electroporation. Thus, we examined whether electroporation induces cell cycle reentry of myonuclei by means of immunohistochemical analyses of PCNA, a cell proliferation marker. Costaining of dystrophin, a marker for sarcolemma, enabled us to distinguish myonuclei from those of mononucleated cells, such as satellite cells. On day 7 after electroporation, PCNA expression in the nuclei of mature myofibers was observed in the area where mononucleated cells infiltrated (Fig. 2A). It should be noted that not all the nuclei within the same myofibers were positive for PCNA. Quantitative analyses revealed that the number of myofibers with PCNA-positive nuclei peaked on day 7 after electroporation (Fig. 2B). These results indicate that electroporation can induce cell cycle reentry of myonuclei.

$B P V C$ injection does not induce cell cycle reentry of myo-
A)
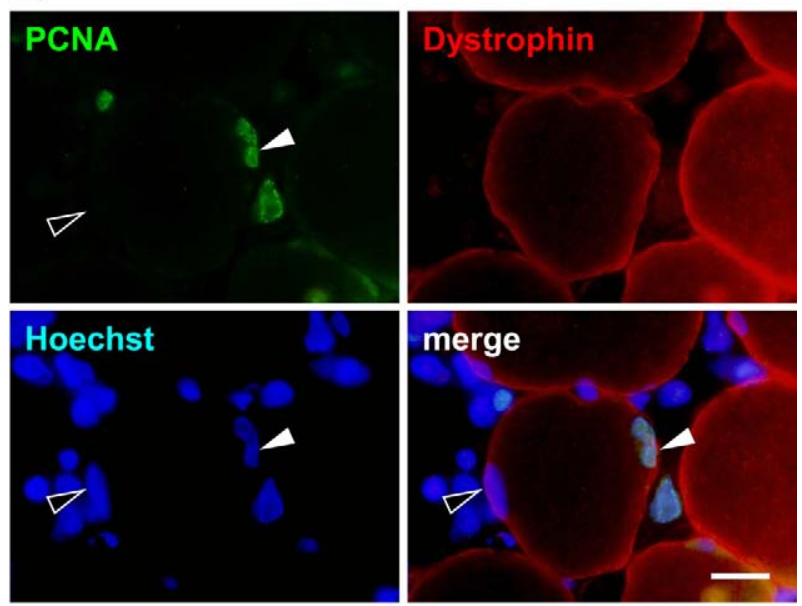

B)

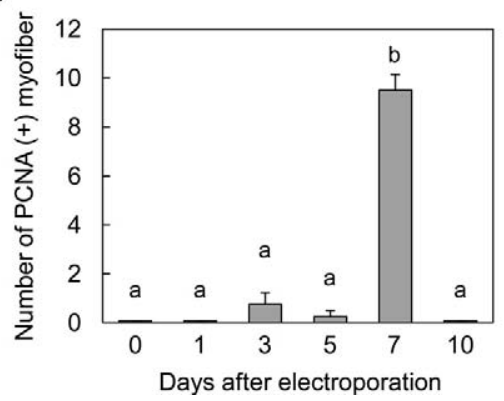

Fig. 2. PCNA expression in myonuclei of rat TA muscles after electroporation. Frozen sections of rat TA muscles obtained on days $1,3,5,7$, and 10 after electroporation with plasmid DNA and untreated (day 0 ) were subjected to immunohistochemistry of PCNA and Dystrophin. (A) Representative photos on day 7. White arrowheads indicate PCNA-positive myonuclei, whereas black arrowheads indicate PCNA-negative myonuclei. Scale bar $=10$ $\mu \mathrm{m}$. (B) The number of PCNA-positive myofibers on entire section was counted. Data are expressed as the means \pm SEM $(n=4$, respectively). Letters ( $a$ and $b$ ) indicate statistically significant differences $(P<0.01)$.

nuclei: In previous studies of inducing regenerative response in mammalian skeletal muscle in vivo, cell cycle reentry of myonuclei has not been observed to our knowledge. Here, in order to investigate whether myonuclei can reenter the cell cycle during regenerative process in general, we examined PCNA expression in myonuclei after BPVC injection into skeletal muscle, since BPVC is known to induce degenerative/regenerative response of skeletal muscle [46].

First, histological analyses were performed on rat TA muscles after BPVC injection. HE staining revealed that on day 3 after BPVC injection, the infiltration of mononucleated cells was observed at the injection site (Fig. 3, Day 3). On day 5, the number of mononucleated cells decreased, and instead, newly formed multinucleated myotubes appeared (Fig. 3, Day 5). The diameter of the regenerating myotubes increased on days 7 and 10 , but the regenerative process 

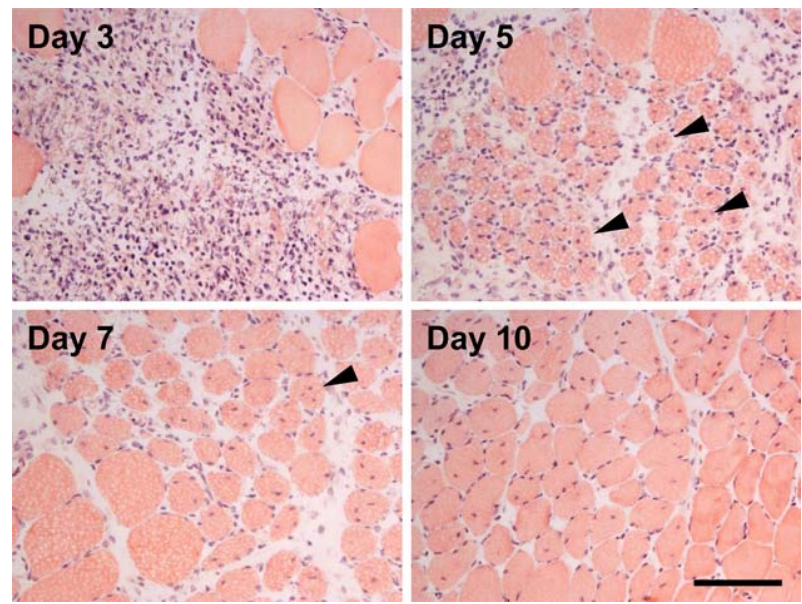

Fig. 3. Histological analyses of rat TA muscles after BPVC injection. Frozen sections of rat TA muscles obtained on days 3, 5, 7, and 10 after BPVC injection were stained with HE. Black arrowheads indicate newly formed myotubes with central nuclei. Scale bar $=100 \mu \mathrm{m}$.

was not yet completed (Fig. 3, Days 7 and 10). Compared with electroporation-induced degeneration/regeneration, the decrease of mononucleated cells in the regenerative process was more rapid after BPVC injection. Double-staining of PCNA and dystrophin revealed that no myonuclei were positive for PCNA at all time points (days 3, 5, 7, and 10 after BPVC injection) examined (data not shown). These results indicate that cell cycle reentry of myonuclei may be the phenomenon observed only in the regenerative process induced by electroporation.

Presence of plasmid DNA is necessary for cell cycle reentry of myonuclei after electroporation: Plasmid DNA increases the damaged area of skeletal muscle after electroporation [12], indicating that the effect of electroporation on skeletal muscle differs depending on the presence of plasmid DNA. To examine whether plasmid DNA influences PCNA expression in myonuclei after electroporation, we investigated the extent of degenerative/regenerative response after electroporation with (EP + plasmid) or without plasmid DNA (EP) (Fig. 4A). Histological analyses on day 7 after electroporation revealed that, although electroporation alone can induce the degenerative/regenerative response of skeletal muscle, it was milder compared with that observed when electroporation was performed in the presence of plasmid DNA. Immunohistochemical analyses of PCNA and dystrophin followed by quantitative analyses of PCNA-positive myonuclei revealed that no PCNA-positive myofibers were observed after electroporation without plasmid DNA (Fig. $4 \mathrm{~B})$, indicating that the presence of plasmid DNA is necessary to induce cell cycle reentry of myonuclei by electroporation.

\section{DISCUSSION}

The present study showed that the electroporation with
A)

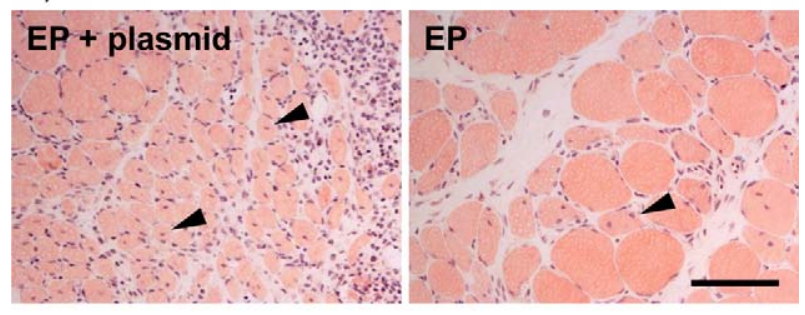

B)

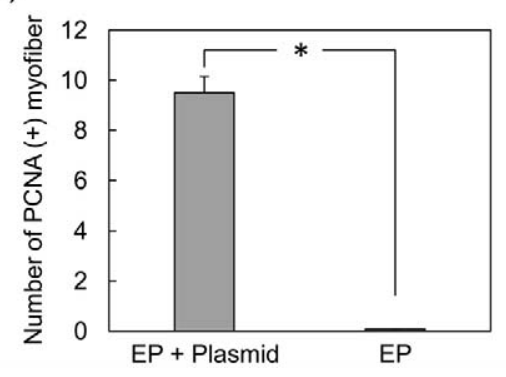

Fig. 4. Histological analyses and PCNA expression in myonuclei of rat TA muscles after electroporation with or without plasmid DNA. Frozen sections of rat TA muscles obtained on day 7 after electroporation with (EP + plasmid) or without plasmid DNA (EP) were stained with $\mathrm{HE}$ (A) or subjected to immunohistochemistry for PCNA and Dystrophin (B), and the number of myofibers with PCNA-positive nuclei on entire sections was counted. In A, Black arrowheads indicate newly formed myotubes with central nuclei. Scale bar $=100 \mu \mathrm{m}$. Data are expressed as the means \pm SEM $(\mathrm{n}=4$, respectively). $* P<0.01$.

plasmid DNA can induce cell cycle reentry of myonuclei, suggesting the occurrence of mammalian skeletal muscle dedifferentiation in vivo.

Cell cycle reentry of myonuclei is considered to be a specific indicator of dedifferentiation [6,33]. Atkinson et al. showed that electroporation to newt appendages and tail induces cell cycle reentry of nuclei within skeletal muscle tissue, and raised the possibility of dedifferentiation of myofibers [3]. In the regenerative process following amputation of newt appendages, not only the myonuclei but also the nuclei of activated satellite cells, which are separated from myofibers by sarcolemma [9], reenter the cell cycle [7, 30]. However, Atkinson et al. did not consider the contribution of the activated satellite cells to the formation of new myofibers. In the present study, we detected PCNA-positive myonuclei residing within the sarcolemma that is visualized by immunostaining of dystrophin, indicating that some nuclei of mature myofibers are capable of reentering the cell cycle after electroporation with plasmid DNA.

The present study showed that not all the nuclei within the same myofiber reenter the cell cycle, and some nuclei remain in a quiescent state. Similar result was obtained following treatment of mouse $\mathrm{C} 2 \mathrm{C} 12$ myotubes with the extract derived from newt regenerating limbs [28]. In the extract treatment study, approximately $64 \%$ of the nuclei within a myotube reentered the cell cycle following the treatment 
with the newt regeneration extract, whereas the remaining nuclei retained quiescent. In addition, the mouse myotubes that responded to the newt regeneration extract were cleaved into smaller myotubes or proliferative mononucleated cells, indicating that even the myofibers that have both the nuclei reentering the cell cycle and remaining in the quiescent state may be able to dedifferentiate after electroporation.

While the electroporation to newt limbs induces cell cycle reentry of nuclei within skeletal muscle tissues, regardless of the presence of plasmid DNA [3], the present study showed that plasmid DNA is essential to the cell cycle reentry of nuclei within myofibers after electroporation. This indicates that the presence or the expression of plasmid DNA can influence the cell cycle reentry of myonuclei of mammals. The gene transfer by injection of naked plasmid DNA or the electroporation into skeletal muscle is transient, and the term of transgene expression is limited due to the immune response $[1,29]$. In fact, the presence of plasmid DNA amplified the immune response after electroporation as evidenced by an increasing number of infiltrating inflammatory cells, indicating that the immune response to the plasmid DNA or the transgene-encoded proteins was evoked. Since plasmid DNA was prepared in E. coli, it could be contaminated with bacterial lipopolysaccharide (LPS) or unmethylated $\mathrm{CpG}$ dinucleotides [4, 42], which may stimulate host innate immunity. Moreover, transforming growth factor- $\beta$ (TGF- $\beta$ ) signaling is shown to be essential for the limb regeneration in axolotls [25]. Thus, it is possible that some cytokines that could induce dedifferentiation such as TGF- $\beta$ are released as a result of immune response, and then these cytokines are induced in reentering the cell cycle of myonuclei.

Electroporation to skeletal muscle induces regenerative response [5, 37]. Several experimental models for the study of skeletal muscle regeneration have been established so far, and BPVC injection into skeletal muscle is one of them [46]. However, there were no myonuclei reentering the cell cycle observed after BPVC injection. The degenerative response after electroporation is thought to be caused by the formation of hydrophilic pores in the cell membrane and the subsequent influx of $\mathrm{Ca}^{2+}$. The pores are resealed spontaneously by self-repairing capability of cells within a few min [41], but if the size or the number of pores is beyond the selfrepairing capability, the influx of $\mathrm{Ca}^{2+}$ may be prolonged or overloaded. The increased concentration of intracellular $\mathrm{Ca}^{2+}$ activates $\mathrm{Ca}^{2+}$-sensitive proteases and lipases, which cause further breakdown of intracellular lipids, proteins and membrane structures such as sarcolemma, resulting in cell death [16]. On the other hand, the myotoxicity of BPVC is caused by the release of $\mathrm{Ca}^{2+}$ from sarcoplasmic reticulum and the inhibition of $\mathrm{Ca}^{2+}$-ATPase on sarcoplasmic reticulum, resulting in the increase of the concentration of intracellular $\mathrm{Ca}^{2+}$ [47]. In addition, BPVC causes mitochondrial dysfunction [20], which leads to the depletion of cellular ATP, the release of mitochondrial $\mathrm{Ca}^{2+}$ into the cytoplasm, and the release of apoptosis factors such as cytochrome $c$ [39], apoptosis-inducing factor [43], Smac-Diablo [8], and endonuclease $\mathrm{G}[23]$. Although there are differences in the source of $\mathrm{Ca}^{2+}$, the increased concentration of intracellular $\mathrm{Ca}^{2+}$ is responsible in common for the degenerative process after electroporation and BPVC injection. However, while cells after electroporation can survive owing to selfrepairing capability, BPVC causes mitochondria-mediated cell death by apoptosis factors. Thus, the cell cycle reentry of myonuclei may be induced by the moderate stimulation of electroporation that is insufficient to induce cell death.

The present study showed the significant increase of the number of myofibers reentering the cell cycle on day 7 after electroporation. In addition, more mononucleated cells were present on days 5 and 7 after electroporation than BPVC injection. The majority of the infiltrated mononucleated cells after electroporation are considered to be macrophages [36]. There are distinct populations of macrophages, and the initial stage of the inflammatory responses driven by Th1 cytokines is dominated by M1 macrophages [18], which cause further muscle damage by producing nitric oxide (NO) [44]. Furthermore, myeloid cells in the early Th1 inflammatory response, including M1 macrophages, can increase myoblasts proliferation, but not muscle cell fusion through induction of TNF- $\alpha$ [22, 24] and IL-6 [45]. These findings suggest that electroporation may induce the prolonged inflammatory response by M1 macrophages and inhibit myogenesis, resulting in the delay of muscle regeneration. Thus, it is possible that, under the condition where muscle differentiation is suppressed, dedifferentiation of myofiber might take place to compensate for deficiency of myotube formation.

In the present study, PCNA was used as a cell proliferation marker. While PCNA plays an essential role as a sliding clamp for DNA polymerase $\delta$ (Pol $\delta$ ) in DNA replication, PCNA and Pol $\delta$ also play essential roles in DNA repair [27]. Therefore, one may argue that the present observation may reflect the process of DNA repair of myofibers rather than cell cycle reentry. In fact, electric pulses cause nicks in the DNA molecules [17]. There are several pathways for DNA damage repair, including nucleotide excision repair (NER), base excision repair (BER), mismatch repair (MMR) and double-strand break repair (DSBR), and all of them involve PCNA. While NER takes less than $10 \mathrm{~min}[14,40]$ and BER completed within $1 \mathrm{hr}$ [15], the expression of PCNA in myonuclei was not observed until day 3 after electroporation. Thus, the expression of PCNA observed in the present study may reflect DNA replication, rather than DNA repair.

In summary, we have shown here the possibility that electroporation with plasmid DNA can induce dedifferentiation of mammalian skeletal muscle. So far, few studies that examined dedifferentiation of mammalian myofibers are present [31]. We show for the first time that the nuclei of mammalian myofibers can reenter the cell cycle in vivo. A further study to clarify the factors that induce cell cycle reentry of mammalian skeletal muscle by electroporation will be necessary for the use of this knowledge to regenerative medicine.

ACKNOWLEDGMENTS. We thank Masahiro Sato for the lacZ plasmid, and Ayako Chiba and Yasuhiko Hayakawa for technical help with electroporation. This work was supported 
by Grant-in-Aid for Scientific Research (23228004) from Japan Society for Promotion of Science.

\section{REFERENCES}

1. Ahlén, G., Söderholm, J., Tjelle, T., Kjeken, R., Frelin, L., Höglund, U., Blomberg, P., Fons, M., Mathiesen, I. and Sällberg, M. 2007. In vivo electroporation enhances the immunogenicity of hepatitis $\mathrm{C}$ virus nonstructural 3/4A DNA by increased local DNA uptake, protein expression, inflammation, and infiltration of $\mathrm{CD}^{+}$T cells. J. Immunol. 179: 4741-4753. [Medline]

2. Aihara, H. and Miyazaki, J. 1998. Gene transfer into muscle by electroporation in vivo. Nat. Biotechnol. 16: 867-870. [Medline] [CrossRef]

3. Atkinson, D. L., Stevenson, T. J., Park, E. J., Riedy, M. D., Milash, B. and Odelberg, S. J. 2006. Cellular electroporation induces dedifferentiation in intact newt limbs. Dev. Biol. 299: 257-271. [Medline] [CrossRef]

4. Ballas, Z. K., Rasmussen, W. L. and Krieg, A. M. 1996. Induction of NK activity in murine and human cells by $\mathrm{CpG}$ motifs in oligodeoxynucleotides and bacterial DNA. J. Immunol. 157: 1840-1845. [Medline]

5. Ban, A., Yamanouchi, K., Matsuwaki, T. and Nishihara, M. 2008. In vivo gene transfer of PPAR gamma is insufficient to induce adipogenesis in skeletal muscle. J. Vet. Med. Sci. 70: 761-767. [Medline] [CrossRef]

6. Brockes, J. P. and Kumar, A. 2005. Appendage regeneration in adult vertebrates and implications for regenerative medicine. Science 310: 1919-1923. [Medline] [CrossRef]

7. Calve, S. and Simon, H. G. 2011. High resolution three-dimensional imaging: evidence for cell cycle reentry in regenerating skeletal muscle. Dev. Dyn. 240: 1233-1239. [Medline] [CrossRef]

8. Chai, J., Du, C., Wu, J. W., Kyin, S., Wang, X. and Shi, Y. 2000. Structural and biochemical basis of apoptotic activation by Smac/DIABLO. Nature 406: 855-862. [Medline] [CrossRef]

9. Chargé, S. B. and Rudnicki, M. A. 2004. Cellular and molecular regulation of muscle regeneration. Physiol. Rev. 84: 209-238. [Medline] [CrossRef]

10. Corcoran, J. P. and Ferretti, P. 1999. RA regulation of keratin expression and myogenesis suggests different ways of regenerating muscle in adult amphibian limbs. J. Cell Sci. 112: 1385-1394. [Medline]

11. Croze, F. and Prud'homme, G. J. 2003. Gene therapy of streptozotocin-induced diabetes by intramuscular delivery of modified preproinsulin genes. J. Gene Med. 5: 425-437. [Medline] [CrossRef]

12. Durieux, A. C., Bonnefoy, R., Busso, T. and Freyssenet, D. 2004. In vivo gene electrotransfer into skeletal muscle: effects of plasmid DNA on the occurrence and extent of muscle damage. $J$. Gene Med. 6: 809-816. [Medline] [CrossRef]

13. Echeverri, K., Clarke, J. D. and Tanaka, E. M. 2001. In vivo imaging indicates muscle fiber dedifferentiation is a major contributor to the regenerating tail blastema. Dev. Biol. 236: 151-164. [Medline] [CrossRef]

14. Erixon, K. and Ahnström, G. 1979. Single-strand breaks in DNA during repair of UV-induced damage in normal human and xeroderma pigmentosum cells as determined by alkaline DNA unwinding and hydroxylapatite chromatography: effects of hydroxyurea, 5-fluorodeoxyuridine and 1-beta-D-arabinofuranosylcytosine on the kinetics of repair. Mutat. Res. 59: 257-271. [Medline] [CrossRef]
15. Fortini, P., Pascucci, B., Parlanti, E., Sobol, R. W., Wilson, S. H. and Dogliotti, E. 1998. Different DNA polymerases are involved in the short- and long-patch base excision repair in mammalian cells. Biochemistry 37: 3575-3580. [Medline] [CrossRef]

16. Gissel, H. and Clausen, T. 2003. $\mathrm{Ca}^{2+}$ uptake and cellular integrity in rat EDL muscle exposed to electrostimulation, electroporation, or A23187. Am. J. Physiol. Regul. Integr. Comp. Physiol. 285: R132-R142. [Medline]

17. Goldberg, A. and Rubinsky, B. 2010. The effect of electroporation type pulsed electric fields on DNA in aqueous solution. Technol. Cancer Res. Treat. 9: 423-430. [Medline]

18. Gordon, S. and Taylor, P. R. 2005. Monocyte and macrophage heterogeneity. Nat. Rev. Immunol. 5: 953-964. [Medline] [CrossRef]

19. Hjiantoniou, E., Anayasa, M., Nicolaou, P., Bantounas, I., Saito, M., Iseki, S., Uney, J. B. and Phylactou, L. A. 2008. Twist induces reversal of myotube formation. Differentiation 76: 182-192. [Medline] [CrossRef]

20. Irwin, W., Fontaine, E., Agnolucci, L., Penzo, D., Betto, R., Bortolotto, S., Reggiani, C., Salviati, G. and Bernardi, P. 2002. Bupivacaine myotoxicity is mediated by mitochondria. J. Biol. Chem. 277: 12221-12227. [Medline] [CrossRef]

21. Kragl, M., Knapp, D., Nacu, E., Khattak, S., Maden, M., Epperlein, H. H. and Tanaka, E. M. 2009. Cells keep a memory of their tissue origin during axolotl limb regeneration. Nature 460: 60-65. [Medline] [CrossRef]

22. Langen, R. C., Van Der Velden, J. L., Schols, A. M., Kelders, M. C., Wouter, E. F. and Janssen-Heininger, Y. M. 2004. Tumor necrosis factor-alpha inhibits myogenic differentiation through MyoD protein destabilization. FASEB J. 18: 227-237. [Medline] [CrossRef]

23. Li, L. Y., Luo, X. and Wang, X. 2001. Endonuclease G is an apoptotic DNase when released from mitochondria. Nature $\mathbf{4 1 2}$ : 95-99. [Medline] [CrossRef]

24. Li, Y. P. 2003. TNF-alpha is a mitogen in skeletal muscle. Am. J. Physiol. Cell Physiol. 285: C370-C376. [Medline]

25. Lévesque, M., Gatien, S., Finnson, K., Desmeules, S., Villiard, É., Pilote, M., Philip, A. and Roy, A. 2007. Transforming growth factor: beta signaling is essential for limb regeneration in axolotls. PLoS ONE 2: e1227. [Medline] [CrossRef]

26. Lucas, M. L., Heller, L., Coppola, D. and Heller, R. 2002. IL-12 plasmid delivery by in vivo electroporation for the successful treatment of established subcutaneous B16.F10 melanoma. Mol. Ther. 5: 668-675. [Medline] [CrossRef]

27. Maga, G. and Hubscher, U. 2003. Proliferating cell nuclear antigen (PCNA): a dancer with many partners. J. Cell Sci. 116: 3051-3060. [Medline] [CrossRef]

28. McGann, C. J., Odelberg, S. J. and Keating, M. T. 2001. Mammalian myotube dedifferentiation induced by newt regeneration extract. Proc. Natl. Acad. Sci. U.S.A. 98: 13699-13704. [Medline] [CrossRef]

29. McMahon, J. M., Wells, K. E., Bamfo, J. E., Cartwright, M. A. and Wells, D. J. 1998. Inflammatory responses following direct injection of plasmid DNA into skeletal muscle. Gene Ther. 5: 1283-1290. [Medline] [CrossRef]

30. Morrison, J. I., Loof, S., He, P. and Simon, A. 2006. Salamander limb regeneration involves the activation of a multipotent skeletal muscle satellite cell population. J. Cell Biol. 172: 433-440. [Medline] [CrossRef]

31. Mu, X., Peng, H., Pan, H., Huard, J. and Li, Y. 2011. Study of muscle cell dedifferentiation after skeletal muscle injury of mice with a Cre-Lox system. PLOS ONE 6: e16699. [Medline] [CrossRef] 
32. Niwa, H., Yamamura, K. and Miyazaki, J. 1991. Efficient selection for high-expression transfectants with a novel eukaryotic vector. Gene 108 193-199. [Medline] [CrossRef]

33. Odelberg, S. J. 2002. Inducing cellular dedifferentiation: a potential method for enhancing endogenous regeneration in mammals. Semin. Cell Dev. Biol. 13: 335-343. [Medline] [CrossRef]

34. Odelberg, S. J. 2005. Cellular plasticity in vertebrate regeneration. Anat. Rec. B New Anat. 287: 25-35. [Medline]

35. Odelberg, S. J., Kollhoff, A. and Keating, M. T. 2000. Dedifferentiation of mammalian myotubes induced by msx1. Cell 103: 1099-1109. [Medline] [CrossRef]

36. Peng, B., Zhao, Y., Xu, L. and Xu, Y. 2007. Electric pulses applied prior to intramuscular DNA vaccination greatly improve the vaccine immunogenicity. Vaccine 25: 2064-2073. [Medline] [CrossRef]

37. Peng, B., Zhao, Y., Lu, H., Pang, W. and Xu, Y. 2005. In vivo plasmid DNA electroporation resulted in transfection of satellite cells and lasting transgene expression in regenerated muscle fibers. Biochem. Biophys. Res. Commun. 338: 1490-1498. [Medline] [CrossRef]

38. Rosania, G. R., Chang, Y. T., Perez, O., Sutherlin, D., Dong, H., Lockhart, D. J. and Schultz, P. G. 2000. Myoseverin, a microtubule-binding molecule with novel cellular effects. Nat. Biotechnol. 18: 304-308. [Medline] [CrossRef]

39. Scorrano, L., Penzo, D., Petronilli, V., Pagano, F. and Bernardi, P. 2001. Arachidonic acid causes cell death through the mitochondrial permeability transition. Implications for tumor necrosis factor-alpha aopototic signaling. J. Biol. Chem. 276: 12035-12040. [Medline] [CrossRef]

40. Shivji, K. K., Kenny, M. K. and Wood, R. D. 1992. Proliferating cell nuclear antigen is required for DNA excision repair. Cell 69: 367-374. [Medline] [CrossRef]

41. Sowers, A. E. and Lieber, M. R. 1986. Electropore diameters, lifetimes, numbers, and locations in individual erythrocyte ghosts. FEBS Lett. 205: 179-184. [Medline] [CrossRef]

42. Stacey, K. J., Sweet, M. J. and Hume, D. A. 1996. Macrophages ingest and are activated by bacterial DNA. J. Immunol. 157: 2116-2122. [Medline]

43. Susin, S. A., Lorenzo, H. K., Zamzami, N., Marzo, I., Snow, B. E., Brothers, G. M., Mangion, J., Jacotot, E., Costantini, P., Loeffler, M., Larochette, N., Goodlett, D. R., Aebersold, R., Siderovski, D. P., Penninger, J. M. and Kroemer, G. 1999. Molecular characterization of mitochondrial apoptosis-inducing factor. Nature 397: 441-446. [Medline] [CrossRef]

44. Villalta, S. A., Nguyen, H. X., Deng, B., Gotoh, T. and Tidball, J. G. 2009. Shifts in macrophage phenotypes and macrophage competition for arginine metabolism affect the severity of muscle pathology in muscular dystrophy. Hum. Mol. Genet. 18: 482-496. [Medline] [CrossRef]

45. Wang, X., Wu, H., Zhang, Z., Liu, S., Yang, J., Chen, X., Fan, M. and Wang, X. 2008. Effects of interleukin-6, leukemia inhibitory factor, and ciliary neurotrophic factor on the proliferation and differentiation of adult human myoblasts. Cell. Mol. Neurobiol. 28: 113-124. [Medline] [CrossRef]

46. Zink, W. and Graf, B. M. 2004. Local anesthetic myotoxicity. Reg. Anesth. Pain Med. 29: 333-340. [Medline]

47. Zink, W., Graf, B. M., Sinner, B., Martin, E., Fink, R. H. and Kunst, G. 2002. Differential effects of bupivacaine on intracellular $\mathrm{Ca}^{2+}$ regulation: potential mechanisms of its myotoxicity. Anesthesiology 97: 710-716. [Medline] [CrossRef] 